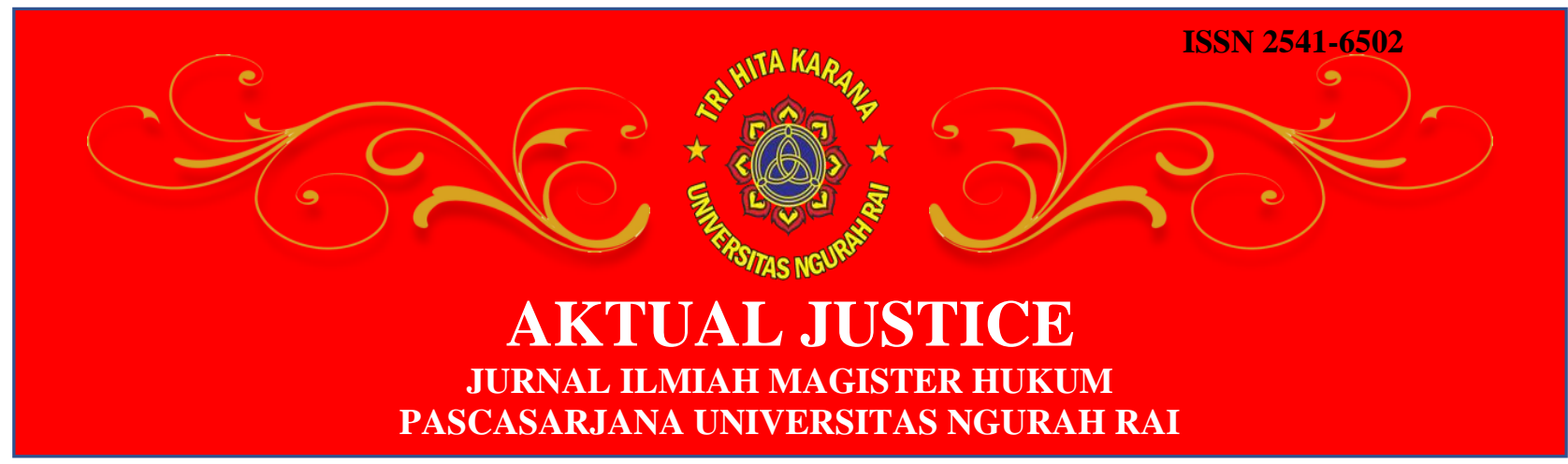

\title{
PEMILU SERENTAK 2019 \\ (PROBLEM DAN SOLUSINYA)
}

\author{
Sukawati Lanang Putra Perbawa
}

Dosen Fakultas Hukum Universitas Mahasaraswati Denpasar,

Email : sukawatilanang@gmail.com

\begin{abstract}
The General Election (Election) according to some circles is a routine agenda that consumes a lot of budget. This assumption is based on the implementation of elections that have been carried out by the Indonesian nation, which have not yet obtained results in accordance with the wishes of the people. In fact, people assume that the implementation of elections from 1955 to 2019 has not been able to produce a government that is according to the mandate in the 1945 Constitution, namely regarding the objectives of the State. Keywords: Election, Indonesia.
\end{abstract}

\section{Abstrak}

Pemilihan Umum (Pemilu) menurut beberapa kalangan merupakan sebuah agenda rutinitas yang menghabiskan banyak anggaran. Anggapan tersebut berdasarkan pada pelaksanaan pemilu yang sudah pernah dilaksanakan oleh bangsa Indonesia belum mendapatkan hasil yang sesuai dengan keinginan masyarakat. Bahkan masyarakat berasumsi bahwa pelaksaan pemilu dari tahun 1955 sampai 2019 ini belum bisa menghasilkan pemerintahan yang sesuai diamanatkan dalam UUD 1945 yaitu mengenai tujuan Negara.

Kata Kunci : Pemilu, Indonesia.

\section{Pendahuluan}

Bangsa Indonesia untuk menjadi Negara demokrasi yang besar didunia, bahkan presiden Amerika Donald Trump pun menyapaikan hal itu dalam forum resmi internasional -KTT Apec di Vietnam. Bangsa kita sudah melalui beberapa era atau rezim, mulai dari orde lama, orde baru, sampai saat ini masuk dalam era reformasi. Pada era reformasi ini, sudah 
memasuki dekade kedua sejak tahun 1998 dengan ditandai peristiwa diturunkannya Presiden Soeharto saat itu. Sejarah mencatat bahwa sejak Indonesia merdeka sampai saat ini sudah berganti sebanyak 7 kali pergantian Presiden. Perjalanan demokrasi kita melahirkan beberapa jenis pemerintahan berlangsung dinegara kita, yang akhirnya era reformasi dengan Demokrasi Pancasila dengan system pemerintahan presidensil menjadi pilihan dan kesepakatan bangsa kita, dengan dituangkannya dalam konstitusi UUD 1945. Untuk menjalankan demokrasi itulah diperlukan pemilihan umum atau dengan kata lain prosedur demokrasi dengan cara pemilu merupakan jalan yang dipilih oleh bangsa-bangsa dunia termasuk Indonesia.

Negara Indonesia merupakan Negara hukum dengan ciri-ciri sebagai Negara modern yang berbasis demokrasi dan berkedaulatan penuh oleh rakyat ${ }^{1}$.Pemilihan Umum merupakan wujud partisipasi politik rakyat dalam sebuah negara demokrasi.Pelaksanaan pemilu yang langsung, umum, bebas, rahasia, jujur dan adil akan menjadi cerminan kualitas demokrasi. Pelaksanaan Pemilihan Umum secara langsung untuk memilih Presiden dan Wakil Presiden, Dewan Perwakilan Rakyat (DPR), Dewan Perwakilan Rakyat Daerah (DPRD), Gubernur dan Wakil Gubernur, Bupati dan Wakil Bupati, Walikota dan Wakil Walikota, merupakan salah satu agenda utama Reformasi di bidang politik

Tujuan Negara yang dimaksud adalah mencapai kesejahteraan masyakat. Pelaksanaan pemilu sebagai simbol pesta demokrasi terus menyisakan berbagai permasalahan yang hadir setelah dilaksanakan, salah satunya adalah permasalahan sengketa hasil pemilu, baik itu pemilu legislative maupun pemilu kepala daerah. Dari masalah ini akhirnya menimbulkan adanya like and dislike diantara pendukung maupun 
masyarakat, yang kemudian menciptakan ketidakharmonisan ditengahtengah masyarakat. Selain itu, pemilu dianggap sebagai sarana untuk melakukan tindak pidana korupsi, karena pemilu di Negara kita masih sarat dengan adanya money politic. Memang berbagai persepsi tersebut merupakan opini yang muncul di masyarakat. Padahal secara kelembagaan Negara permasalahan pemilu yaitu mengenai cost and benefit. Maksudnya adalah bagaimana pemerintah bisa melaksanakan pemilu dengan anggaran yang sedikit tapi mampu menghasilkan output pemilu yang bagus. Pemilihan Umum 2019 bakal digelar secara berbeda dengan pemilu sebelumnya. Yakni Pemilu Legislatif (Pileg) dan Pemilihan Presiden (Pilpres) akan dilaksanakan serentak. Berbeda dengan Pemilu 2014 yang dilakukan terpisah. Pileg pada 9 April 2014 dan Pilpres pada 9 Juli 2014. Keputusan itu merupakan tindak lanjut dari permohonan uji materi Undang-Undang Nomor 42 Tahun 2008 tentang Pemilihan Presiden dan Wakil Presiden (UU Pilpres) yang diajukan Koalisi Masyarakat Sipil, yang meminta pemilu serentak. Dalam gugatannya, koalisi meminta agar pileg mulai dari DPRD, DPD, DPR, dan pilpres harus dilakukan secara serentak. Sehingga pemilu yang selama ini dilakukan 2 kali pencoblosan disatukan menjadi 1 kali pencoblosan. Pasca Putusan Mahkamah Konstitusi No. 14/PUU-XI/2013 yang mengabulkan sebagian permohonan uji materi (judicial review) Undang-Undang Nomor 42 Tahun 2008 Tentang Pemilihan Umum Presiden dan Wakil Presiden yang diajukan Effendi Gazali dkk aturan pemilu serentak ini muncul, keluarnya putusan MK ini merupakan salah satu terobosan hukum baru. Dimana dalam amar putusannya MK menyatakan: Pasal 3 Ayat (5), Pasal 12 Ayat (1) dan Ayat (2), Pasal 14 Ayat (2), dan Pasal 112 Undang-Undang Nomor 42 Tahun 2008 tidak mempunyai kekuatan hukum mengikat (inkonstitusional). Dari rangkaian ketentuan yang dinyatakan kehilangan validitas konstitusional tersebut, MK menegaskan, pemilihan umum presiden dan wakil presiden harus 
dilaksanakan serentak dengan pemilihan umum anggota DPR, DPD, dan DPRD. Dengan putusan ini, ketentuan bahwa Pemilihan Umum Presiden dan Wakil Presiden (Pemilu Presiden) dilaksanakan setelahPemilihan Umum anggota DPR, DPD, dan DPRD (Pemilu Legislatif) adalah inkonstitusional, dalam diktum kedua dari amar putusan Mahkamah Konstitusi menegaskan bahwa putusan pemilu serentak akan diterapkan pada pemilu 2019.

\section{Metode Penelitian}

Penelitian ini merupakan penelitian deskriptif kualitatif dengan telaah teori berdasarkan kajian pustaka dan penelitian yang relevan. Kajian pustaka memiliki peranan penting dalam penelitian, yakni untuk mendasari dan memperkokoh gagasan peneliti. Idealnya, literatur yang dikaji merupakan sumber asli dari artikel maupun jurnal ilmiah².

\section{Hasil Dan Pembahasan}

Reformasi konstitusi dilakukan utuk menguatkan sistem politik demokratis.Pasal 2 ayat (1) Undang-Undang Dasar Negara Republik Indonesia Tahun 1945 menyatakan bahwa kedaulatan berada ditangan rakyat dan dilaksanakan menurut Undang-Undang Dasar.Makna dari "kedaulatan berada ditangan rakyat ${ }^{3 "}$ dalam hal ini ialah bahwa rakyat memiliki kedaulatan, tanggung jawab hak dan kewajiban untuk secara demokratis memilih pemimpinyang akanmembentuk pemerintahan. Indonesia akan menjalani babak baru praktik demokrasi dengan penyelenggaraan Pemilu serentak 2019, yang terdiri dari pemilihan presiden dan wakil presiden digabung dengan pemilihan anggota DPR,

2 Sugiyono. (2015). Metodologi Penelitian. Bandung: Alfabeta. h.113.

${ }^{3}$ Fahmi, K. (2010). Prinsip Kedaulatan Rakyat Dalam Penentuan Sistem Pemilihan Umum Anggota Legislatif. Jurnal Konstitusi, Volume 7, Nomor 3, Juni 2010, h. 124. 
DPRD Provinsi dan DPRD Kabupaten/Kota. Ada beberapa kelebihan bila dilakukan serentak, yaitu efesiensi dana pelaksanaan pemilu, menjaga psikologi pemilih, hingga meminimalisasir kemungkinan konflik sosial akibat ketegangan politik berkepanjangan. Selain itu memperkuat system presidensil, dengan memaksa akan adanay koalisi permanen. Pemerintah hasil pilihan rakyat inilah yang akan berguna mengurus dan melayani seluruh lapisan masyarakat.

Pemilu Serentak 2019 adalah penyelenggaraan pemilu legislatif dengan eksekutif yang dilakukan secara bersamaan. Keputusan ini dikeluarkan melalui Keputusan Mahkamah Konstitusi (MK) No 14/PUU11/2013 Tentang Pemilihan Umum Serentak. Pada putusan tersebut, MK berdasarkan pertimbangan, bahwa penyelenggaraan Pemilu dua kali, yaitu Pemilu Legislatif dan Pemilu Presiden yang diselenggarakan secara terpisah bertentangan dengan UUD 1945, dimana pasal 22E menyebutkan bahwa pemilu secara berkala, 5 tahun sekali dilakukan untuk memilih anggota DPR, DPR, DPRD, Presiden dan Wakil Presiden. Dalam upaya mensukseskan hajat bangsa untuk terselenggaranya pemilu serentak tahun 2019, diperlukan kerjasama dan sinergitas semua pihak untuk ikut mensukseskannya. Setidaknya ada 5 (lima) aspek yang perlu dilakukan dalam upaya suksesi pemilu serentak 2019 yaitu:Pertama, perlunya undang-undang yang aspiratif dan aplikatif sebagai payung hukum serta desain model pemilu serentak 2019. Jika merujuk pada sejarah perundangundangan sebelum era reformasi 1998, hampir lebih dari tiga puluh tahun dimasa Orde Baru perpolitikan bangsa mencermikan demokrasi yang kurang sehat, praktek demokrasi di Indonesia terbelenggu tanpa adanya kebebasan mengemukakan hak dan pendapat dimuka umum.

Hukum yang konservatif memiliki beberapa karakteristik antara lain: (1) Proses pembuatannya sentralistik (tidak partisipatif) karena didominasi oleh lembaga-lembaga negara yang dibentuk secara tidak 
demokrastis pula oleh negara. Di sini peran lembaga peradilan dan kekuatan-kekuatan masyarakat sangat sumir; (2) Isinya bersifat positivistinstrumentalistik (tidak aspiratif) dalam arti lebih mencerminkan kehendak penguasa karena sejak semula hukum telah dijadikan alat (instrumen) pembenar yang akan maupun (terlanjur) dilakukan oleh pemegang kekuasaan yang dominan; (3) Lingkup isinya bersifat open responsive (tidak responsif) sehingga mudah ditafsir secara sepihak dan dipaksakan penerimanya oleh pemegang kekuasaan negara; (4) Pelaksanaannya lebih mengutamakan program dan kebijakan sektoral jangka pendek daripada menegakkan aturan-aturan hukum yang resmi berlaku; (5) Penegakannya lebih mengutamakan perlindungan korp sehingga tidak jarang pembelokan kasus hukum oleh aparat dengan mengaburkan kasus pelanggaran menjadi kasus prosedur atau menampilkan kambang hitam sebagai pelaku yang harus dihukum.

Karakteristik hukum konservatif tersebut di atas menjadi tidak relevan dalam konteks saat ini, era reformasi menuntut hukum dan perundangan yang dibuat harus lebih aspiratif, responsif, dan aplikatif untuk kepentingan bangsa dan negara. Formulasi perundang-undangan harus mampu menampung aspirasi pemikiran lapisan masyarakat dan karakteristik bangsa Indonesia sehingga produk hukum yang dihasilkan dapat diterima oleh seluruh lapisan masyarakat. Dengan disahkannya UU Pemilu 2019 tentu masyarakat berharap bahwa Pemilu 2019 dapat menjadi lebih baik lagi dibandingkan dengan model dan sistem pemilu sebelumnya. UU Pemiluharus menjadi semangat bersama dalam membenahi sistem pemilu di Indonesia sehingga mutu demokrasi di Indonesia semakin baik.

UU Pemilu 2019 telah disahkan dengan pilihan opsi A yang berisi: (a) Presidential Threshold sebesar 20-25 persen, aturan ini mensyaratkan partai politik atau gabungan parpol harus memiliki 20 persen jumlah kursi di DPR dan/atau 25 persen suara sah nasional di pemilu sebelumnya untuk 
pengajuan calon presiden dan wakil presiden. (b) Parliamentary Threshold sebesar 4 persen menjadi prasyarat parpol untuk kader/wakilnya dapat duduk sebagai anggota dewan. (c) Sistem Pemilu yang dipilih dalam pemilu 2019 adaalah sistem proporsional terbuka. (d) Dapil Magnitude 3-10, yaitu alokasi daerah pemilihan yakni rentang jumlah kursi anggota DPR di setiap daerah pemilihan. Berdasarkan Pasal 22 ayat (2) UU Nomor 8/2012 disebutkan jumlah kursi di setiap dapil anggota DPR paling sedikit 3 kursi dan paling banyak 10 kursi. (e) Metode konversi suara model Sainte Lague murni, metode sainte lague ini dalam melakukan penghitungan suara bersifat proporsional yaitu tidak ada pembedaan dan tidak memihak apakah itu partai kecil ataupun partai besar. Metode konversi suara ini mempengaruhi jumlah kursi setiap parpol yang lolos ke DPR. Metode sainte lague murni menerapkan bilangan pembagi suara berangka ganjil seperti, $1,3,5,7,9$, dan seterusnya. Metode sainte lague ini dalam melakukan penghitungan suara bersifat proporsional yaitu tidak ada pembedaan dan tidak memihak apakah itu partai kecil ataupun partai besar.

Kedua, perlunya penyelenggara pemilu yang kapabel dan profesional.Secara khusus komisioner KPU periode 2017-2022 memiliki tanggungjawab lebih berat dalam menjalankan tugasnya, mereka akan mengambil alih proses pelaksanaan pilkada serentak tahun 2018 yang saat ini sudah dipersiapkan oleh komisioner KPU sebelumnya. Tugas berat lainnya adalah melakukan perencanaan pelaksanaan pemilu serentak 2019 yang belum pernah ada contoh-nya di negeri ini, hal ini tentu memerlukan konsolidasi dan kekompakan internal KPU dalammelakukan manajerial pemilu mendatang. KPU sebagai lembaga resmi penyelenggara pemilu memiliki tanggungjawab besar dalam melaksanakan pemilu yang profesional, mandiri, berintegrasi dan bebas dari kepentingan politik. Komisioner KPU tidak hanya dituntut cakap dan kapabel dalam 
menjalankan tanggungjawab menyelenggarakanpemilu, tapi juga tuntutan netralitas dari sikap dan pandangan politiknya.

Dalam catatan Perludem hal lain yang perlu dilakukan dalam penyelenggaraan pemilu adalah perlunya penguatan Bawaslu sebagai suatu badan pengawas pemilu, yakni dengan memberikan kewenangan quasiyudisial. Yaitu, berupa fungsi ajudikasi (perwasitan), sehingga Bawaslu bisa memutus pelanggaran dan sengketa pemilu. Posisi Bawaslu yang saat ini terkesan hanya sebagai pengawas pemilu saja perlu diberikan kewenangan yang lebih besar terutama dalam mensikapi dan menindak sengketa yang muncul dalam pemilu.

Ketiga, perlunya uji publik efektivitas pembiayaan pemilu serentak. Jika melihat pada data Bappenas penyelenggaraan pemilu 2009 yang mencapai 8,5 triliun dan mengalami kenaikan biaya pada pemilu 2014 yang mencapai 16 triliun. Maka secara logika pelaksanaan pemilu serentak 2019 seyogyanya membutuhkan biaya yang lebih murah dan minim. Hal ini dikarenakan model pemilu 2019 akan berbeda dengan skema model pemilu sebelumnya. Penyelenggaraan Pemilu legislatif dan Presiden dan Wakil Presiden tahun 2009 dan 2014 dilakukan secara terpisah, sedangkan rencana pelaksanaan pemilu 2019 akan dilakukan secara serentak dalam hari yang sama untuk memilih anggota legislatif,serta memilih presiden dan wakil presiden.

Biaya penyelenggaraan pemilu 2019 yang berasal dari APBN harus benar-benar dibuat lebih efisien dan efektif. Penyelenggaraan pemilu yang bersih, transparan dan akuntabel dalam pengelolaan uang negara akan mening-katkan kepercayaan masyarakat kepada negara. Penyelenggara pemilu dapat melakukan efisiensi anggaran terutama dalam penyediaan logistik pemilu dan sosialisasi pemilu. Dalam hal efisiensi logistik KPU dapat menggunakan kotak pemungutan suara, tinta dan alat pencoblos ekspilkada serentak 2018 sedangkan untuk pelaksanaan sosialisasi pemilu, 
KPU dapat bekerjasama dengan lembaga pendidikan seperti sekolah, kampus, dan pondok pesantren.

Berdasarkan riset Indonesia Budget Center (IBC) untuk Pemilu tahun 2004 dan 2009 beberapa titik yang rawan dalam pengelolaan anggaran pemilu adalah terkait dengan urusan logistik yaitu: lelang kotak suara, lelang kertas suara, sistem distribusi logistik, dan lelang tinta. Lemahnya pengawasan anggaran pemilu juga sering terjadi pada anggaran pengamanan dan pengawasan serta adanya rangkap anggaran sosialisasi pemilu antar satu kementerian dengan kementerian lainnya. Dengan dilakukannya proses sosialisasi kepada masyarakat sejak pembuatan rencana anggaran biaya pemilu maka masyarakat akanlebih tahu dan ikut berpartisipasi dalam proses efektivitas pembiayaan pemilu.

Keempat, perlunya kesiapanpartai politik dalam pemilu serentak. Diperlukan kesiapan dalam manajerial organisasi di internal partai politik sehingga bisa ikut menjadi peserta pemilu serentak 2019 serta kesiapan manajerial eksternal partai politik dalam membangun komunikasi politik dengan partai politik lainnya serta dengan masyarakat. Dalam perkembangan sistem politik Indonesia telah menempatkan partai politik sebagai pilar utama penyangga jalannya demokrasi, keberadaan partai politik menjadi ciri bahwa demokrasi masih berjalan dengan baik di Indonesia. Dalam UU Nomor 2 Tahun 2011 Tentang Partai Politik disebutkan bahwa "Partai Politik adalah organisasi yang bersifat nasional dan dibentuk oleh sekelompok warga negara Indonesia secara sukarela atas dasar kesamaan kehendak dan cita-cita untuk memperjuangkan dan membela kepentingan politik anggota, masyarakat, bangsa dan negara, serta memelihara keutuhan Negara Kesatuan Republik Indonesia berdasarkan Pancasila dan Undang-Undang Dasar Negara Republik Indonesia Tahun 1945". Substansinya adalah partai politik dapat ikut berperan aktif dalam menegakan demokrasi dan kesatuan NKRI. Diantara 
peran partai politik adalah dengan memberikan pendidikan politik yang berkarakter kebangsaan kepada masyarakat. Pendidikan politik ini menjadi penting sebagai sarana partai politik dalam upaya mencerdaskan kehidupan bangsa. Masalah yang akan dihadapi dalam pemilu serentak adalah sebagai berikut:

Pertama adalah terkait administrasi, dari proses pencalonan, pengaturan kampanye sampai dengan prosees pencoblosan dan rekapitulasi suara. Meskipun administrasi tampak sepele, namun tantangan administrasi adalah hal yang paling disoroti. Bahkan KPU mencacat ada 12 permasalahan yang muncul dalam pilkada serentak yakni mulai dari penyerahan surat dukungan hingga tahapan penetapan calon. Temuan masalah administrasi seperti temuan dokumen palsu, dualisme kepengurusan partai politik, status kesehatan hingga status tersangka dari pasangan calon. Hal-hal seperti itu akan menyita perhatian dan tenaga KPU di tengah persiapan lain yang harus diselesaikan.

Kedua adalah terkait polemik calon tunggal untuk Pemilu Presiden, dan legitimasi pencalonan capres, parpol yang mana yang berhak mencalonkan. Putusan Mahkamah Konstitusi (MK) yang menyatakan bahwa calon tunggal tetap bisa mengikuti Pilkada serentak 2015 tak dapat diundur hingga 2017. Putusan MK juga membuka peluang untuk ditempuh jalur referendum bagi daerah yang memiliki calon tunggal. Apabila pilihan setuju lebih banyak maka pasangan calon ditetapkan menjadi kepala daerah. Sementara jika tidak setuju memperoleh suara terbanyak maka Pilkada akan ditunda sampai pemilihan berikutnya. Padahal tujuan Pilkada serentak itu adalah meningkatkan efisiensi politik elektoral. Ketiga adalah terkait electoral body, baik KPU maupun Bawaslu, selain memang sedang proses transisi pergantian, juga kaitan dengan kinerja masing-masing. Pemilu serentak yang akan digelar untuk pertama kalinya itu masih banyak kelemahan yang perlu diawasi. Banyknya kemungkinan 
pelanggaran menjadi tugas berat baik KPU maupun Bawaslu. Walaupun pengawasan tak hanya dilakukan instansi pemerintah namun juga masyarakat secara umum, tapi sebagai ujung tombak tetap lembaga penyelenggara yang menjadi strategis dan penting. Tujuannya adalah untuk menjaga kualitas pemilu yang demokratis, berintegritas dan hasil yang berkuaitas.

Keempat adalah tantangan konflik. Dalam tantangan ini memang lebih dikhusukan pada pelaksaanaan pemilu. Konfigurasi dukungan di masyarakat untuk pemilu legeslatif yang bersamaaan denga Pilpres akan membawa konfigurasi konflik yang makin tinggi, apalagi bila calon legeslatif berpaket dengan capres yang diusung

\section{Kesimpulan}

Dalam mengantisipasi pelaksanaan pemilu serentak tidak terjadi banyak problem diatas ada beberapa hal yang harus dilakukan, diantaranya:

Pertama, seluruh stakeholder baik parpol, penyelenggara, pemerintah dan masyarakat harus menjalankan fungsi dan tugasnya masing-masing yang maksimal untuk memberikan informasi dan pengetahuan tentang pemilu, dan pentingnya menjaga keamanan dalam proses pemilu serentak dan bila ada sengketa dilakukan dengan cara-cara penegakan hokum sesuai dengan peraturan. Seperti partai politik memiliki empat peran dan fungsi, yaitu sebagai sarana komunikasi politik, sebagai sarana kaderisasi, sebagai sarana sosialisasi politik, dan sebagai pengatur konflik. Parpol dan masyarakat dalam pelaksanaan pemilu menolak untuk terjadinya money politic atau politik transaksional. Tapi sebaiknya mendorong pemilu yang tanpa transaksional dan mendorong pemilu yang rasional.

Kedua, Penegakan hokum yang terintegrasi baik menyangkut administrasi maupun pidana. Dari KPU, Bawaslu, polisi, jaksa, dan hakim harus mempunyai persepsi dan pemahaman yang sama terhadap penegakan 
hokum terkait masalah pemilu. Terutama juga dengan Mahkamah Konsitusi yang pintu akhir sengketa pemilu kaitan siapa yang dimenangkan atau dikalahkan dalam perebutan kursi baik legeslatif dan eksekutif.

Ketiga, pendidikan politik bagi masyarkat untuk bisa mendorong budaya politik yang cerdas dan tertib dengan tetap menjalankan hak dan kewajibanya. Semua pihak harus melakukan komunikasi dan kordinasi yang intensif dan terbuka untuk menjaga demokrasi yang berintegritas sekaligus control lembaga bagi lembaga lain termasuk control bagi masyarakat.

\section{DAFTAR PUSTAKA}

Huda, N.M. (2010). Hukum Tata Negara. Jakarta: PT.Raja Grafido Persada

Fahmi, K. (2010). Prinsip Kedaulatan Rakyat Dalam Penentuan Sistem Pemilihan Umum Anggota Legislatif. Jurnal Konstitusi, Volume 7, Nomor 3, Juni 2010

Sugiyono. (2015). Metodologi Penelitian. Bandung: Alfabeta 